\title{
Draft Statement on the Reproduction of Manuscripts and Archives for Commercial Purposes
}

The following statement was prepared by the Committee on Manuscripts Collections of the Rare Books and Manuscripts Section of the Association of College and Research Libraries. It is a revised version of the "Draft Statement on the Reproduction of Manuscripts and Archives for Commercial Purposes" which was published in the March 1975 issue of College \& Research Libraries News (p.96-97). It will be considered for approval by the ACRL Board of Directors at the 1977 Midwinter Meeting, in Washington, D.C.

All comments and suggestions concerning the statement should be sent to the chairman of the committee, Vesta Lee Gordon, Special Collections Librarian, James Branch Cabell Library, Virginia Commonwealth University, Richmond, Virginia 23220.

Material to be deleted is enclosed in brackets. Material to be added is underscored.

1. It is the responsibility of libraries, archives, or manuscript repositories to facilitate access to original collections by permitting commercial publishing companies to reproduce, reprint, or otherwise publish certain collections in their [its] possession, unless:

a. the physical condition of the originals prohibits reproduction;

b. there are legal restrictions which prohibit or limit reproduction of the originals.

2. No repository shall be expected to reproduce a complete manuscript collection or archival record group.

3. The commercial publisher shall agree to the following conditions:

a. Permission. (1) The publisher shall be responsible for compliance with all copyright and other legal requirements applicable to reproduction of the ma- terial borrowed and will obtain (and will deliver to the repository [owning institution] a duplicate executed counterpart of) all such consents, licenses, and other instruments as may be necessary for such compliance. (2) The publisher shall agree to indemnify and hold harmless the repository [owning institution], its officers and employees, any and all of them, against and from any liability, loss, cost or expense whatsoever, including attorney's fees, which the repository [owning institution], its officers and employees, any and all of them, may at any time incur arising out of or relating to the reproduction of any of its manuscripts or other original material.

b. Acknowledgment. The publisher shall cause the reproduction of any manuscript collection or archival record group to show that it has been made from an original in the library of the owning repository [institution] in the form specified by the repository.

c. Quality of Reproduction. The publisher shall cause his reproduction to be of a quality satisfactory to the repository [institution] from which he has borrowed the originals. A hard copy reproduction should meet current minimal standards for binding and paper as formulated by the Library of Congress and by the Resources and Technical Services Division, a division of the American Library Association. [and] If published on microfilm, the reproductions shall meet the minimum specificaContinued on page 289 


\section{Draft Statement}

Continued from page 273

tions in Specifications for the Microfilming of Books and Pamphlets in the Library of Congress (Washington, D.C., Library of Congress, 1973) [standards for microfilming established by the Library of Congress]. In addition, the following American national standards, published by the American National Standards Institute, shall be adhered to:

1. Specifications for Safety Photographic Film, ANSI PH1.25-1974.

2. Methylene Blue Method for Measuring Thiosulfate and Silver Densitometric Method for Measuring Residual Chemicals in Films, Plates, and Papers, ANSI PH4.8-197I.

3. Specifications for $16 \mathrm{~mm}$ and $35 \mathrm{~mm}$ Silver Gelatin Microfilms for Reel Applications, ANSI PH5.3-1967 (R1973).

4. Practice for Storage of Processed Silver Gelatin Microfilm, ANSI PH5.4-1970.

5. Dimensions for 100-Foot Reels for Processed $16 \mathrm{~mm}$ and $35 \mathrm{~mm}$ Microfilm, ANSI PH5.6-1968 (R1974).

6. Microfiche of Documents, ANSI PH5.9-1975.

7. Microfilm Package Labeling, ANSI PH5.19-1975.

8. Practice for Inspection and Quality Control of First Generation Silver Halide Microfilm, ANSI PH5.23.

9. Operational Procedures for the Production of Microforms, ANSI PH5.24.

[If the reproduction is published in book form, the publisher must use permanent paper (as defined by the Barrow Laboratories, Richmond, Virginia).]

d. [e.] Reproduction. The owning repository [institution] shall specify when and where the reproductions are to be made and the conditions under which they will be made.

e. [d.] The Original. (1) The publisher will not permit original manuscripts or other archival materials to suffer physical damage while in his care. Should damage occur, all repairs are to be made by qualified conservators chosen [in accordance with guidelines estab- lished] by the owning repository [institution] and at the expense of the publisher. (2) If the archival or manuscript materials are damaged beyond repair, the publisher must return the materials to the owning repository and reimburse the owning repository [institution] at the value set by an independent appraiser who is jointly selected and therefore satisfactory to both the publisher and the owning repository [institution]. The publisher must pay the appraiser's fee.

f. Royalties. The owning repository [institution] shall receive from the publisher (1) an agreed royalty which has been established in advance by legal contract and (2) a sufficient number of copies of the publisher's reproduction for the repository's [institution's] internal use.

g. Restrictions. The publisher must respect any restrictions placed upon reproductions or copies of original manuscripts or archival materials furnished to him.

h. Pricing. The publisher shall agree to market his reproductions using a nondiscriminating price structure.

4. a. Both the owning repository [institution] and the publisher must inform purchasers of reproductions that permission to make extensive direct quotations or to print any reproduction in full must be obtained from the owning repository [institution]. Every reproduction must bear a clear statement to this effect.

b. Manuscripts must not be published without due regard for literary property rights (also known as common law rights), personal property rights, libel, and unwarranted invasions of privacy [common law rights, literary rights, property rights, and libel laws].

\section{Are You a Pilot?}

All pilot librarians interested in forming an association of flying librarians (tentatively called PAL, Pilots Association of Librarians), contact: David C. Genaway, Associate Dean of Libraries, John G. Crabbe Library, Eastern Kentucky University, Richmond, KY 40475.

Possible activities include fly-ins, special dinners at conferences, etc. 


\section{SOUTHEAST ASIX;; \\ Bibliographic Directions in a Complex Area}

by Paul Bixler

Less is known about Southeast Asia than any other part of the world-no area is in greater need of clarification, understanding, and informative context. Mr. Bixler points the college librarian, the undergraduate student, and the general reader toward a basic knowledge of Burma, Thailand, Indochina, Cambodia, Laos, Vietnam, Indonesia, Malaysia, Singapore, Brunei, the Philippines, and the Overseas Chinese. A revised and updated edition of Southeast Asia Studies; A Basic Bibliography (CHOICE 1972-1973), this essay covers government, economics, education, the arts, history, literature, and anthropology, forming a pattern of human and bibliographical ecology. Mr. Bixler, Librarian Emeritus of Antioch Callege and Consultant to the Ford Foundation, was the General Editor of the five-part Libraries in the Far East published in Library Journal.

"Mr. Bixler's work is not only the product of an internationally recognized librarian, it is also the outcome of his many years of study and field experience in Southeast Asia."-Frank N. Trager, New York University.

96 pages 478 title entries $\quad 81 \frac{1 / 2 \times 11}{} \quad$ Index $\quad$ Bibliographies $\quad$ Paperbound $\quad \$ 4.75$

\section{MARITIME HISTORY A Basic Bibliography \\ by Edward W. Sloan III \\ (Reprinted from CHOICE, September 1972)}

Often dismissed as a haven for the antiquarian or armchair browser, maritime history is in fact a field distinguished by works of scholarly precision-and often by striking literary felicity. While unavoidably fragmented, it nonetheless has as its bond the fundamental, pervasive, and unending confrontation of man with the sea. Dr. Sloan demonstrates this by organizing his material under such subjects as American \& British Maritime Activities; The Sea, Ships, and Shipbuilding; Science and Navigation; War and the Merchant Marine; Privateering and Piracy; Whaling and Fishing; and many others. Dr. Sloan is Associate Professor of History at Trinity College, Hartford.

17 pages

379 title entries

$81 / 2 \times 11$

Bibliographies

Paperbound

$\$ 2.00$

Publications Dept.

\section{Groice}

100 Riverview Center

Middletown, Conn. 06457

Please enclose

remittance with order.
MARITIME HISTORY; A Basic Bibliography

SOUTHEAST ASIA; Bibliographic Directions in a Complex Area

NAME

ADDRESS

Zip 